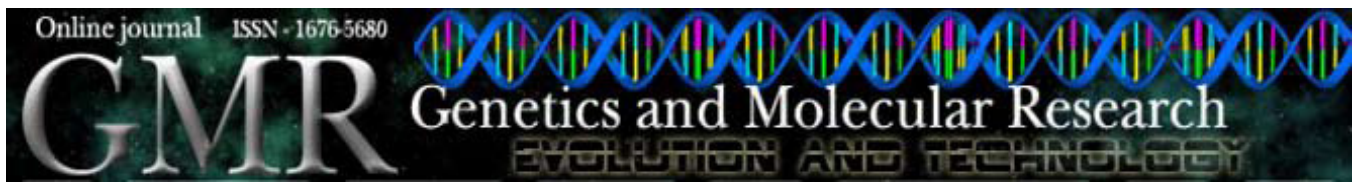

\title{
Diversity of endophytic bacteria in Brazilian sugarcane
} \author{
and E.M. Souza ${ }^{1}$ \\ ${ }^{1}$ Departamento de Bioquímica e Biologia Molecular, \\ Universidade Federal do Paraná, Curitiba, PR, Brasil \\ ${ }^{2}$ Departamento de Patologia Médica, \\ Universidade Federal do Paraná, Curitiba, PR, Brasil \\ ${ }^{3}$ Universidade Estadual de Goiás, Goiânia, GO, Brasil \\ Corresponding author: E.M. Souza \\ E-mail: souzaem@ufpr.br
}

G.S. Magnani ${ }^{1}$, C.M. Didonet ${ }^{3}$, L.M. Cruz ${ }^{1}$, C.F. Picheth ${ }^{2}$, F.O. Pedrosa ${ }^{1}$

Genet. Mol. Res. 9 (1): 250-258 (2010)

Received October 28, 2009

Accepted January 3, 2009

Published February 9, 2010

\begin{abstract}
Endophytic bacteria live inside plant tissues without causing disease. Studies of endophytes in sugarcane have focused on the isolation of diazotrophic bacteria. We examined the diversity of endophytic bacteria in the internal tissues of sugarcane stems and leaves, using molecular and biochemical methods. Potato-agar medium was used to cultivate the endophytes; 32 isolates were selected for analysis. DNA was extracted and the 16S rRNA gene was partially sequenced and used for molecular identification. Gram staining, catalase and oxidase tests, and the API-20E system were used to characterize the isolates. The strains were divided into five groups, based on the 16S rRNA sequences. Group I comprised 14 representatives of the Enterobacteriaceae; group II was composed of Bacilli; group III contained one representative, Curtobacterium sp; group IV contained representatives of the Pseudomonadaceae family, and group $\mathrm{V}$ had one isolate with an uncultured bacterium. Four isolates were able to reduce acetylene to ethylene. Most of the bacteria isolated from the sugarcane stem and leaf tissues belonged to Enterobacteriaceae and Pseudomonaceae, respectively, demonstrating niche specificity. Overall, we found the endophytic bacteria in sugarcane to be
\end{abstract}


more diverse than previously reported.

Key words: Endophytic bacterium; Microbial diversity; Sugarcane; $16 \mathrm{~S}$ rRNA

\section{INTRODUCTION}

Sugarcane (Saccharum spp) is one of the most important crops in Brazil, with a yield of $495 \mathrm{M}$ tons in 2007/2008 (UNICA, 2009), a quarter of the world's production. Its two main products are sugar and alcohol, a clean renewable alternative fuel. This crop is perhaps the most economically competitive source of ethanol and can effectively contribute to a cleaner environment. Ways of improving its productivity are subject to intense investigation in Brazil, chiefly because worldwide climate change due to the intense use of greenhouse gas-producing energy sources has resulted in substantial focus on the development of sustainable energy.

Endophytic bacteria occupy internal tissues of plants without causing damage to their hosts (Hallmann et al., 1997). This microbial community could play an important role in agriculture by conferring advantages to the plant (Mengoni et al., 2003), since endophytic bacteria can contribute to plant development by producing phytohormones (Feng et al., 2006) and siderophores (Burd et al., 1998), increasing resistance to pathogens (Reiter et al., 2002) and parasites (Hallmann et al., 1997), and promoting biological nitrogen fixation (Baldani et al., 1986) and antibiotic production (Strobel and Daisy, 2003). Understanding the diversity of plant-bacterial associations and their role in plant development is necessary if these associations are to be manipulated to increase crop production, conserve biodiversity and sustain agro-ecosystems (Germida et al., 1998; Sturz et al., 1999).

Bacterial endophytes are found in a variety of plants, such as sugar beet (Dent et al., 2004), prairie plants, agronomic crops (Zinniel et al., 2002), potato varieties (Sessitsch et al., 2002), wheat (Germida and Siciliano, 2001), and rice (Sun et al., 2008). The microbial community of endophytes colonizes plant tissues and is capable of establishing interactions not only among themselves but also with invaders such as pathogens, and in this way may influence plant development. For example, Araújo et al. (2002) described interactions between the phytopathogenic bacterium Xylella fastidiosa and endophytes in Citrus sinensis, which apparently restricted the development of the disease by suppressing the symptoms in inoculated plants.

In sugarcane, most of the research on endophytic bacteria has focused on diazotrophs, of which the main representatives are Gluconacetobacter diazotrophicus, Herbaspirillum spp (Baldani et al., 1986; Cavalcante and Döbereiner, 1988) and Azospirillum amazonense (Reis Júnior et al., 2000). However, the presence of diazotrophs among the total population of bacteria in sugarcane tissues seems to be low in Indian sugarcane (Suman et al., 2001). The aim of this study was to investigate the diversity of the putative endophytic population in stems and leaves of Brazilian sugarcane.

\section{MATERIAL AND METHODS}

\section{Bacterial isolation and identification}

Sugarcane plants were from a 4-year-old plantation in the northeast of Paraná State (Brazil). The plants were grown for livestock feeding. Sugarcane leaves and stems 
were collected and then separated and maintained in ice until analysis. The leaves were washed with sterile distilled water and their surface disinfected by washing with $70 \%$ ethanol. The stems were treated in the same way, and after disinfection, were flame sterilized. Stems $(10 \mathrm{~g})$ and leaves $(10 \mathrm{~g})$ were macerated separately in sterile $10 \mathrm{mM}$ Tris- $\mathrm{HCl}, \mathrm{pH} 8.0$, and serially diluted to $10^{-6}$. One hundred microliters of these dilutions was plated on potato-agar (Döbereiner et al., 1995) and incubated at $30^{\circ} \mathrm{C}$ for up to 5 days. Thirty-two isolates from stems and leaves of sugarcane, representing different types of colonies developed on agar, were randomly chosen, analyzed by gram stain, cytochrome oxidase activity (Gram-negative rods) or catalase production (Gram-positive cocci) (Koneman et al., 2001). The Gram-negative rods were plated on MacConkey medium (Miller, 1992) to identify candidate Enterobacteriaceae, and then submitted to biochemical analysis using the API-20E test (bioMérieux).

\section{Amplification and sequencing of the 16S rRNA gene}

Three milliliters of fresh cultures of the isolates in LB medium was used for DNA extraction according to Sambrook et al. (1989). Genomic DNA was used as a template in a polymerase chain reaction (PCR) with the primers Y1 (5'-TGGCTCAGAACGAACGCTG GCGGC-3') and Y2 (5'-TACCTTGTTACGACTTCACCCCAGTC-3'), allowing amplification of a fragment of approximately $300 \mathrm{bp}$ of the 5' end of the 16S rRNA gene. The PCR mixtures contained 50-100 ng template DNA, $2.5 \mu \mathrm{L}$ 10X Taq buffer (200 mM Tris-HCl, $\mathrm{pH}$ 8.4, $500 \mathrm{mM} \mathrm{KCl}$ ), $1.5 \mathrm{mM} \mathrm{MgCl}_{2}, 0.2 \mathrm{mM}$ dNTP, $4 \mathrm{pM} \mathrm{Y} 1$ and Y2 primers, and $1.0 \mathrm{U}$ Taq DNA polymerase in $25 \mu \mathrm{L}$. The temperature cycles were: $94^{\circ} \mathrm{C} / 30 \mathrm{~s}$ (once); $94^{\circ} \mathrm{C} / 20 \mathrm{~s}, 58^{\circ} \mathrm{C} / 20 \mathrm{~s}$, $72^{\circ} \mathrm{C} / 1 \mathrm{~min}$ (30 times), and $72^{\circ} \mathrm{C} / 5 \mathrm{~min}$ (once).

The Y1-Y2 PCR products were purified using the AutoSeq 96 System (GE HealthCare) and sequenced using dye terminator chemistry and an ABI PRISM 377 sequencer (Applied Biosystems).

\section{Sequence assembly and analysis}

The PHRED program was used for base calling (Ewing et al., 1998). The forward and reverse sequences were assembled with the CAP3 program (Huang and Madan, 1999). Nucleotide sequence identities were determined by the BLAST and Seqmatch programs. The 16S rRNA genes have been deposited in GenBank (EF054896-EF054920/FJ966050-FJ966056).

\section{Determination of nitrogenase activity}

To test for nitrogenase activity in the Enterobacteriaceae, $100 \mu \mathrm{L}$ of the cultures grown in LB was added to $4 \mathrm{~mL}$ NFDM (Dixon et al., 1977) medium containing $0.5 \mathrm{mM}$ sodium glutamate in $10-\mathrm{mL}$ bottles, which were sealed with suba-seals and incubated at $30^{\circ} \mathrm{C}$ in a rotary shaker $(120 \mathrm{rpm})$ for $16 \mathrm{~h}$. Acetylene $(10 \%)$ was then injected into the culture vials, incubated for $1 \mathrm{~h}$ and analyzed for ethylene by gas chromatography. To test for nitrogenase activity in the Pseudomonads, $100 \mu \mathrm{L}$ of the cultures grown in NfbHPN was added to inoculate $4 \mathrm{~mL}$ semisolid $\mathrm{N}$-free $\mathrm{NfbHN}$ and acetylene reduction activity was determined as described (Pedrosa and Yates, 1984). 


\section{RESULTS}

\section{Phenotypic characterization of the sugarcane isolates}

Thirty-two isolates representing all colony types developed on potato-agar cultures from macerates of leaves and stems were randomly selected and stored in 50\% glycerol at $-20^{\circ} \mathrm{C}$. Of these, 18 strains were isolated from stems (designated as CC), and 14 strains from leaves (FC). Frozen cultures were re-streaked on potato-agar, and isolated colonies of each culture were selected.

Most of the isolates were Gram-negative bacilli. The exceptions were strains CC18, a Gram-positive coccus, and strains $\mathrm{CC} 38$ and $\mathrm{CC} 27$, which were Gram-positive bacilli. All the Gram-negative bacilli were oxidase negative, but only 14 of 29 of these grew on MacConkey agar; these were tested using the API-20E kit for enteric bacteria. Based on the API and oxidase results, these 14 strains were classified as Enterobacteriaceae (Table 1), among which were Enterobacter (CC14, CC26, CC29, CC33, CC34, CC37, CC43, CC46, FC2P), Pantoea (CC16, CC21, CC47), Kluyvera (CC20), and Klebsiella (CC22). An interesting observation is that all but one strain of this group (FC2P) were isolated from sugarcane stems. The Gram-positive isolates were catalase positive.

\section{Sequence analysis}

The 5' end of the 16S rRNA gene of the 32 isolates was amplified by PCR and sequenced. At least two sequencing reactions were performed for each direction and the assembled sequences, with primer sequences removed, had lengths ranging from 275 to $301 \mathrm{bp}$.

The 16S rRNA sequences were used to search the GenBank and RDP databases using Blast and SequeMatch programs, respectively. Most of the strains (28) belonged to the gamma Proteobacteria. The results allowed clustering the sugarcane endophytic bacteria into 5 distinct groups. Group I was composed of members of the Enterobacteriaceae family. The isolates of this group were related to Pantoea (4), Enterobacter (8), Klebsiella (1), and Citrobacter (1). Again, all but one strain of the enteric bacteria group (FC2P) were isolated from sugarcane stems.

Group II comprised two isolates of the Bacilli class, which probably belong to the Brevibacillus (CC38) and Staphylococcus (CC18) genera. Group III had a single representative of the Actinobacteria phylum (CC27) related to Curtobacterium. Group IV contained 14 strains related to Pseudomonadaceae, which were all isolated from leaves with 2 exceptions (CC24 and CC35). Although most Pseudomonads are oxidase positive, all the isolates in this study were oxidase negative. Group V had only one isolate, related to an uncultured bacterium.

The endophytic population in the stem is more diverse than that of the leaves: the stem harbored a larger number (8) of different genera distributed in all four groups with prevalence of Enterobacteriaceae, whereas bacterial strains isolated from leaves belonged to only 2 genera with a large predominance of Pseudomonas.

\section{Screening for endophytic nitrogen-fixing bacteria}

Approximately $90 \%$ of these isolates showed no nitrogenase activity: only iso- 


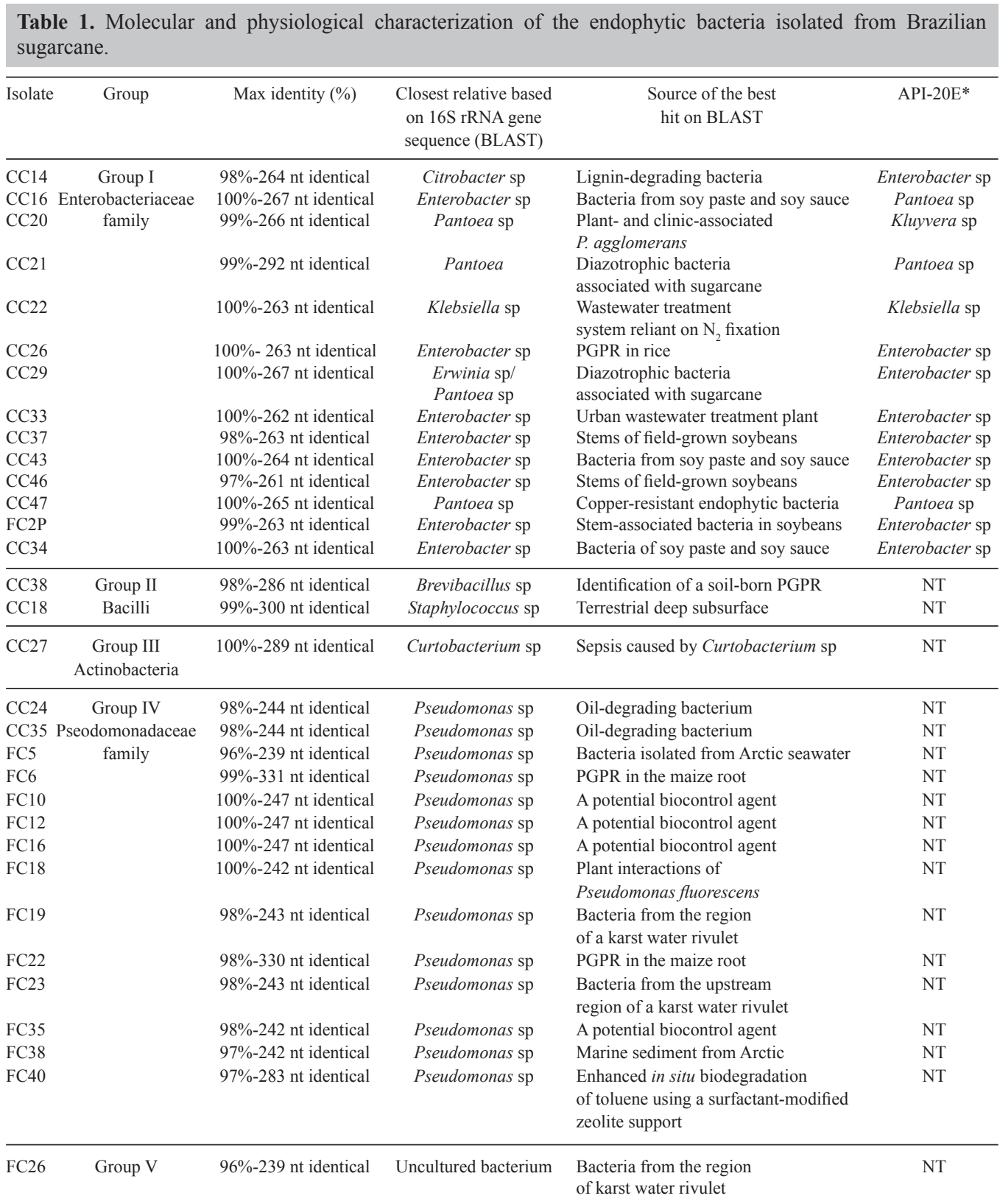

$\mathrm{NT}=$ not tested; $\mathrm{nt}=$ nucleotides; PGPR $=$ plant growth-promoting Rhizobacteria. ${ }^{*}$ Only strains that grew on MacConkey agar were tested with API-20E.

lates $\mathrm{CC} 22, \mathrm{CC} 26, \mathrm{CC} 29$, and CC35 reduced acetylene to ethylene. Based on 16S rRNA sequence identity, these isolated were tentatively classified as Klebsiella, Enterobacter, Pantoea, and Pseudomonas. 


\section{DISCUSSION}

Plants maintain a complex ecosystem where bacterial communities interact continuously, competing for nutrients and water in the tissues of the host. Knowledge of the diversity of endophytic bacteria is important for both ecological and biotechnological studies.

Most studies of sugarcane endophytes have focused on the diazotrophic bacteria (Cavalcante and Döbereiner, 1988; Caballero-Mellado and Martinez-Romero, 1994; Olivares et al., 1996). Since factors other than biological nitrogen fixation can contribute significantly to the host, we investigated the diversity of bacteria from leaves and stems of sugarcane. In our study, the prevalence of diazotrophs was very low: only $10 \%$ of the isolates had nitrogenase activity. The absence of endophytic diazotrophs such as Gluconacetobacter diazotrophicus, Herbaspirillum spp, Burkholderia spp, and Azospirillum spp, which have been found in great numbers in sugarcane, is most notable. This discrepancy may be due to the use of nitrogen-free medium for bacterial isolation, geographic and environmental variations or a combination of these. In a study similar to ours, Suman et al. (2001) isolated endophytic bacteria from several cultivars of Indian sugarcane on LGI medium and found that the prevalence of diazotrophs varied from 3.86 to $0.02 \%$. It is possible that by using a rich medium such as potato-agar medium, which supports the growth of many different bacteria, a distinct portion of the bacterial community was assessed, suggesting a more complex ecology of sugarcane endophytes than previously reported.

In this study, the fermenting Gram-negative bacilli were characterized both by phenotypic identification and 16S rRNA gene sequencing. The identifications obtained by these methods agreed at the genus level in 11 of 14 isolates. In the remaining cases, the identifications were of closely related genera. These discrepancies may be due to limited databases available for the phenotypic test systems and to the fact that the system used was designed for clinical diagnostics: the closest sequence matches to our isolates were always either plant endophytes or from other environmental sources, which are unlikely to be represented in the API-20E system database.

The Enterobacter genus was the most frequently found in the stems. Enterobacter has been identified as endophytes of several plants such as Citrus sinensis, soybean and crop plants (Araújo et al., 2002; Zinniel et al., 2002; Kuklinsky-Sobral et al., 2004). Other Enterobacteriaceae identified in sugarcane have also been previously described as endophytes. The plant growth-promoting bacterium Kluyvera ascorbata SUD165, resistant to heavy metals, was capable of conferring resistance to high concentrations of nickel to canola and tomato plants (Burd et al., 1998). Endophytic Pantoea was found in sugarcane (Loiret et al., 2004) and in soybean (Kuklinsky-Sobral et al., 2004). Representatives of these three genera have also been associated with pathogenicity (Gurtler et al., 2005; Medrano and Bell, 2007). However, the results suggest no dominance of a particular strain, indicating that a pathogenic association was unlikely. Furthermore, a completely different bacterial community, dominated by Pseudomonas, was identified in the leaves.

The two Bacilli genera identified in sugarcane have been identified before as endophytes: Staphylococcus was found to be associated with sweet pepper (Rasche et al., 2006) and Brevibacillus was found in cadmium-contaminated soils and associated with soybean (Sarkar et al., 2002; Vivas et al., 2003). Curtobacterium, the only representative of the Actinobacteria, was identified in orange, grape, and Pinus (Bell et al., 1995; Araújo et al., 2002; Idris et al., 2004), and interacting with the phytopathogenic bacterium Xylella fastidiosa (Lacava et al., 2004). To our 
knowledge, this is the first characterization of Brevibacillus and Curtobacterium in sugarcane.

The microbial population of sugarcane leaves, colonized predominantly by Pseudomonaceae, and sugarcane stems, with prevalence of Enterobacteriaceae, were substantially different. Stems presumably offer a more stable niche for the bacteria, since they contain a greater diversity of genera: they are less exposed to drastic changes of their physicochemical conditions such as temperature, humidity, UV irradiation, and nutrients in the apoplast. In contrast, the more frequent variation of the environmental conditions of the leaves can restrict the growth of bacterial populations (Hirano and Upper, 2000). For example, the varying exudates of leaves impose a metabolic versatility on bacteria, a characteristic of the Pseudomonas genus (Mercier and Lindow, 2000; Misko and Germida, 2002). This preference for different habitats has already been shown in other plants (Sessitsch et al., 2002; Mocali et al., 2003).

The results reported here suggest that the population of sugarcane endophytes can vary depending on the plant organ analyzed. It is noteworthy that the relative number of diazotrophic endophytes recovered was low, perhaps reflecting the lack of selective pressure in the isolation procedure. Further studies will be necessary to thoroughly analyze the endophytic population of sugarcane, including collection of plants from different geographic origins and the use of culture-independent molecular analyses.

\section{ACKNOWLEDGMENTS}

We thank Valter A. de Baura, Roseli Prado and Julieta Pie for technical support, and M.G. Yates for reading the manuscript. Research supported by CNPq - Instituto do Milênio, PRONEX - Fundação Araucária and CAPES.

\section{REFERENCES}

Araújo WL, Marcon J, Maccheroni W Jr, Van Elsas JD, et al. (2002). Diversity of endophytic bacterial populations and their interaction with Xylella fastidiosa in citrus plants. Appl. Environ. Microbiol. 68: 4906-4914.

Baldani JI, Baldani VLD, Seldin L and Döbereiner J (1986). Characterization of Herbaspirillum seropedicae gen. nov., sp. nov., a root-associated nitrogen-fixing bacterium. Int. J. Syst. Bacteriol. 36: 86-93.

Bell CR, Dickie GA, Harvey WLG and Chan JWYF (1995). Endophytic bacteria in grapevine. Can. J. Microbiol. 41: 46-53.

Burd GI, Dixon DG and Glick BR (1998). A plant growth-promoting bacterium that decreases nickel toxicity in seedlings. Appl. Environ. Microbiol. 64: 3663-3668.

Caballero-Mellado J and Martinez-Romero E (1994). Limited genetic diversity in the endophytic sugarcane bacterium Acetobacter diazotrophicus. Appl. Environ. Microbiol. 60: 1532-1537.

Cavalcante VA and Döbereiner J (1988). A new acid-tolerant nitrogen-fixing bacterium associated with sugarcane. Plant Soil 108: 23-31.

Dent KC, Stephen JR and Finch-Savage WE (2004). Molecular profiling of microbial communities associated with seeds of Beta vulgaris subsp. vulgaris (sugar beet). J. Microbiol. Methods 56: 17-26.

Dixon R, Kennedy C, Kondorosi A, Krishnapillai V, et al. (1977). Complementation analysis of Klebsiella pneumoniae mutants defective in nitrogen fixation. Mol. Gen. Genet. 157: 189-198.

Döbereiner J, Baldani VLD and Baldani JI (1995). Meios de Culturas e Soluções Utilizadas. In: Como Isolar e Identificar Bactérias Diazotróficas de Plantas Não-Leguminosas (Motta AC, Oliveira MAS, Martins FC and Quazi TSG, eds.). CNPAB-Embrapa, Brasília, 47-53.

Ewing B, Hillier L, Wendl MC and Green P (1998). Base-calling of automated sequencer traces using phred. I. Accuracy assessment. Genome Res. 8: 175-185.

Feng Y, Shen D and Song W (2006). Rice endophyte Pantoea agglomerans YS19 promotes host plant growth and affects allocations of host photosynthates. J. Appl. Microbiol. 100: 938-945.

Germida JJ and Siciliano SD (2001). Taxonomic diversity of bacteria associated with the roots of modern, recent and 
ancient wheat cultivars. Biol. Fertil. Soils 33: 410-415.

Germida JJ, Siciliano SD, Freitas R and Seib AM (1998). Diversity of root-associated bacteria associated with field-grown canola (Brassica napus L.) and wheat (Tritricum aestivum L.). FEMS Microbiol. Ecol. 26: 43-50.

Gurtler JB, Kornacki JL and Beuchat LR (2005). Enterobacter sakazakii: a coliform of increased concern to infant health. Int. J. Food Microbiol. 104: 1-34.

Hallmann J, Mahaffee WF, Kloepper JW and Quadthallmann A (1997). Bacterial endophytes in agricultural crops. Can. J. Microbiol. 43: 895-914.

Hirano SS and Upper CD (2000). Bacteria in the leaf ecosystem with emphasis on Pseudomonas syringae - a pathogen, ice nucleus, and epiphyte. Microbiol. Mol. Biol. Rev. 64: 624-653.

Huang X and Madan A (1999). CAP3: A DNA sequence assembly program. Genome Res. 9: 868-877.

Idris R, Trifonova R, Puschenreiter M, Wenzel WW, et al. (2004). Bacterial communities associated with flowering plants of the Ni hyperaccumulator Thlaspi goesingense. Appl. Environ. Microbiol. 70: 2667-2677.

Koneman EW, Allen SD, Janda WM, Schreckenberger PC, et al. (2001). Diagnóstico Microbiológico. Texto e Atlas Colorido. 5th edn. MEDSI Editora Médica e Científica, Rio de Janeiro.

Kuklinsky-Sobral J, Araújo WL, Mendes R, Geraldi IO, et al. (2004). Isolation and characterization of soybean-associated bacteria and their potential for plant growth promotion. Environ. Microbiol. 6: 1244-1251.

Lacava PT, Araujo WL, Marcon J, Maccheroni W Jr, et al. (2004). Interaction between endophytic bacteria from citrus plants and the phytopathogenic bacteria Xylella fastidiosa, causal agent of citrus-variegated chlorosis. Lett. Appl. Microbiol. 39: 55-59.

Loiret FG, Ortega E, Kleiner D, Ortega-Rodes P, et al. (2004). A putative new endophytic nitrogen-fixing bacterium Pantoea sp. from sugarcane. J. Appl. Microbiol. 97: 504-511.

Medrano EG and Bell AA (2007). Role of Pantoea agglomerans in opportunistic bacterial seed and boll rot of cotton (Gossypium hirsutum) grown in the field. J. Appl. Microbiol. 102: 134-143.

Mengoni A, Mocali S, Surico G, Tegli S, et al. (2003). Fluctuation of endophytic bacteria and phytoplasmosis in elm trees. Microbiol. Res. 158: 363-369.

Mercier J and Lindow SE (2000). Role of leaf surface sugars in colonization of plants by bacterial epiphytes. Appl. Environ. Microbiol. 66: 369-374.

Miller JH (1992). A Short Course in Bacterial Genetics: A Laboratory Manual and Handbook for Escherichia coli and Related Bacteria. Cold Spring Harbor Laboratory Press, New York.

Misko AL and Germida JJ (2002). Taxonomic and functional diversity of pseudomonads isolated from the roots of fieldgrown canola. FEMS Microbiol. Ecol. 42: 399-407.

Mocali S, Bertelli E, Di CF, Mengoni A, et al. (2003). Fluctuation of bacteria isolated from elm tissues during different seasons and from different plant organs. Res. Microbiol. 154: 105-114.

Olivares FL, Baldani VLD, Reis VM, Baldani JI, et al. (1996). Occurrence of the endophytic diazotrophs Herbaspirillum spp. in roots, stems, and leaves, predominantly of Gramineae. Biol. Fertil. Soils 21: 197-200.

Pedrosa SO and Yates MG (1984). Regulation of nitrogen fixation (nif) genes of Azospirillum brasilense by nifA and ntr ( $g l n)$ type gene products. FEMS Microbiol. Lett. 23: 95-101.

Rasche F, Trondl R, Naglreiter C, Reichenauer TG, et al. (2006). Chilling and cultivar type affect the diversity of bacterial endophytes colonizing sweet pepper (Capsicum anuum L.). Can. J. Microbiol. 52: 1036-1045.

Reis Júnior FB, Silva LG, Reis VM and Döbereiner J (2000). Occurrence of diazothrophic bacteria in different sugar cane genotypes. [Ocorrência de bactérias diazotróficas em diferentes genótipos de cana-de-açúcar]. Pesq. Agropec. Bras. 35: 985-994.

Reiter B, Pfeifer U, Schwab H and Sessitsch A (2002). Response of endophytic bacterial communities in potato plants to infection with Erwinia carotovora subsp. atroseptica. Appl. Environ. Microbiol. 68: 2261-2268.

Sambrook J, Fritsch EF and Maniatis T (1989). Molecular Cloning: a Laboratory Manual. 2nd edn. Cold Spring Harbor Laboratory Press, Cold Spring Harbor.

Sarkar PK, Hasenack B and Nout MJ (2002). Diversity and functionality of Bacillus and related genera isolated from spontaneously fermented soybeans (Indian Kinema) and locust beans (African Soumbala). Int. J. Food Microbiol. 77: 175-186.

Sessitsch A, Reiter B, Pfeifer U and Wilhelm E (2002). Cultivation-independent population analysis of bacterial endophytes in three potato varieties based on eubacterial and Actinomycetes-specific PCR of 16S rRNA genes. FEMS Microbiol. Ecol. 39: 23-32.

Strobel G and Daisy B (2003). Bioprospecting for microbial endophytes and their natural products. Microbiol. Mol. Biol. Rev. 67: 491-502.

Sturz AV, Christie BR, Matheson BG, Arsenault WJ, et al. (1999). Endophytic bacterial communities in the periderm of potato tubers and their potential to improve resistance to soil-borne plant pathogens. Plant Pathol. 48: 360-369.

Suman A, Shasany AK, Singh M, Shahi HN, et al. (2001). Molecular assessment of diversity among endophytic diazotrophs 
isolated from subtropical Indian sugarcane. World J. Microbiol. Biotechnol. 17: 39-45.

Sun L, Qiu F, Zhang X, Dai X, et al. (2008). Endophytic bacterial diversity in rice (Oryza sativa L.) roots estimated by $16 \mathrm{~S}$ rDNA sequence analysis. Microb. Ecol. 55: 415-424.

UNICA (União da Indústria da Cana-de-Açúcar) (2009). Dados e Cotações - Estatísticas. Available at [http://www.unica. com.br/dadosCotacao/estatistica/]. Accessed October 19, 2009.

Vivas A, Voros I, Biro B, Campos E, et al. (2003). Symbiotic efficiency of autochthonous arbuscular mycorrhizal fungus (G. mosseae) and Brevibacillus sp. isolated from cadmium polluted soil under increasing cadmium levels. Environ. Pollut. 126: 179-189.

Zinniel DK, Lambrecht P, Harris NB, Feng Z, et al. (2002). Isolation and characterization of endophytic colonizing bacteria from agronomic crops and prairie plants. Appl. Environ. Microbiol. 68: 2198-2208. 